\title{
Anaerotruncus colihominis gen. nov., sp. nov., from human faeces
}

Correspondence

Sydney M. Finegold

sidfinegol@aol.com

\author{
Paul A. Lawson, ${ }^{1}$ Yuli Song, ${ }^{2}$ Chengxu Liu, ${ }^{2}$ Denise R. Molitoris, ${ }^{2}$ \\ Marja-Liisa Vaisanen, ${ }^{2}$ Matthew D. Collins ${ }^{1}$ and Sydney M. Finegold ${ }^{3,4,5}$ \\ ${ }^{1}$ School of Biosciences, University of Reading, UK \\ ${ }^{2,3}$ Research Service ${ }^{2}$ and Infectious Diseases Section ${ }^{3}$, VA Medical Center West Los Angeles, \\ LA, USA \\ ${ }^{4,5}$ Department of Medicine ${ }^{4}$ and Department of Microbiology, Immunology and Molecular \\ Genetics $^{5}$, UCLA School of Medicine, USA
}

The human large intestine harbours a highly diverse and complex community of bacteria that play an important role in the health and physiological function of the host (Ducluzeau, 1988; Gibson \& Roberfroid, 1995). Although the intestinal microbiota has been investigated in great detail over many years by using anaerobic culturing techniques, it is now recognized universally that the human gut contains many unknown bacteria. By using cultureindependent techniques, such as PCR rDNA direct community sequence analysis, it is now clear that the great majority of bacteria within the gut and faeces belong to three major phylogenetic groups: the Bacteroides group, the Clostridium coccoides group and the Clostridium leptum subgroup (Wilson \& Blitchington, 1996; Suau et al., 1999). Furthermore, it is now evident from these studies that the majority of rDNA lineages generated are derived from hitherto undescribed species. Although it is possible that much of this novel diversity may represent non-culturable organisms, it nevertheless seems likely that many others have simply eluded taxonomic description, due to the

Published online ahead of print on 29 August 2003 as DOI 10.1099/ ijs.0.02653-0.

Abbreviations: CCUG, Culture Collection of the University of Göteborg; CIP, Collection de I'Institut Pasteur; WAL, Wadsworth Anaerobic Laboratory.

The GenBank/EMBL/DDBJ accession number for the 16S rRNA gene sequence of strain WAL $14565^{\top}$ is AJ315980. limitations of traditional phenotypic methods of identification. It is recognized that $16 \mathrm{~S}$ rRNA gene sequencing, used in concert with culturing techniques, represents a powerful approach for discerning novel species diversity within the human gut and faeces (e.g. Barcenilla et al., 2000; Steer et al., 2001; Taras et al., 2002). In the present study, we have used this approach to facilitate the identification of two isolates of a hitherto unknown species within the C. leptum subgroup. Based on the presented findings, we describe a novel genus and species, Anaerotruncus colihominis gen. nov., sp. nov.

Two isolates were recovered from stool specimens of children with late-onset autism at the Rush Childrens Hospital, Chicago, USA. Neither child had been on antimicrobials. Strain WAL $14565^{\mathrm{T}}$ was recovered from faecal material of a 71-month-old male child and strain WAL 15976 was recovered from a 60-month-old male child. Neither child had ever had any contact with the other. The entire stool specimens were homogenized by using a sterile stainless steel blender with one to three volumes of peptone $(0.05 \%)$ added as diluent, if required. An aliquot of each specimen (approx. $1 \mathrm{~g}$ in weight) was used to make serial tenfold dilutions in pre-reduced, anaerobically sterilized (PRAS) dilution blanks (Anaerobe Systems). A $100 \mu \mathrm{l}$ aliquot of each dilution was plated onto Brucella blood agar (Anaerobe Systems) and incubated anaerobically at $37^{\circ} \mathrm{C}$ under an $\mathrm{N}_{2} / \mathrm{CO}_{2}(80: 20, \mathrm{v} / \mathrm{v})$ gas phase. All colonies with unique colony morphology on the preliminary isolation 
plates were selected for purification. The strains did not come up as pure cultures; they were purified by repeated streaking. The strains were characterized biochemically by using a combination of conventional tests, as described in the Wadsworth and VPI anaerobic manuals (Holdeman et al., 1977; Jousimies-Somer et al., 2002) and in the API ZYM and Rapid ID 32A (bioMérieux) and AN MicroPlate (Biolog) systems, according to the instructions of the respective manufacturer. Substrate utilization was examined by using peptone/yeast/sugar broth tubes (Anaerobe Systems). All biochemical tests were performed in duplicate. The DNA $\mathrm{G}+\mathrm{C}$ content was determined by HPLC according to Mesbah et al. (1989), except that the methanol content of the chromatographic buffer was reduced to $8 \%$ and the temperature was increased to $37^{\circ} \mathrm{C} .16 \mathrm{~S}$ rRNA genes of the isolates were amplified by PCR and sequenced directly by using a Taq DyeDeoxy Terminator Cycle Sequencing kit and a model 373A automatic DNA sequencer (both from Applied Biosystems). The closest known relatives of the new isolates were determined by performing database searches with the program FASTA (Lipman \& Pearson, 1985). These sequences and those of other known related strains were retrieved from GenBank or the Ribosomal Database Project (RDP) database and aligned with the newly determined sequence by using the program DNATools (Rasmussen, 1995). The resulting multiple sequence alignment was corrected manually by using the program GeneDoc (Nicholas et al., 1997) and a phylogenetic tree was constructed according to the neighbour-joining method with the programs DNATools and TREEVIEW (Page, 1996). Stability of the groupings was estimated by bootstrap analysis (1000 replications) using the same programs.

The isolates that originated from faecal material consisted of anaerobic, Gram-positive, fairly thin $(0.5 \times 2-5 \mu \mathrm{m})$ rods. Spores were not observed (Fig. 1). After $48 \mathrm{~h}$ anaerobic incubation at $37^{\circ} \mathrm{C}$ under an $\mathrm{N}_{2} / \mathrm{CO}_{2}(80: 20, \mathrm{v} / \mathrm{v})$ gas phase, colonies were $2-3 \mathrm{~mm}$ in diameter, grey, entireedged, irregularly shaped, low pyramidal in profile and translucent. The isolates grew well anaerobically, but no growth occurred following subculture in an atmosphere of 2 or $6 \% \mathrm{O}_{2}$. The $\mathrm{pH}$ range for growth was $5 \cdot 5-11$ and the growth temperature range was $36-40{ }^{\circ} \mathrm{C}$. They were catalasenegative and did not reduce nitrate to nitrite, but were indole-positive. They were inhibited by bile. Glucose was fermented, with the production of acid and gas. Analysis of metabolic end products by GLC from peptone/yeast/ glucose broth revealed only acetic and butyric acids, but no organic acids. Both isolates failed to hydrolyse aesculin, gelatin or urea. $\mathrm{H}_{2} \mathrm{~S}$ was produced by both strains. They were able to grow in peptone/yeast broth supplemented with $1 \%$ glucose, fructose, mannose or cellobiose, but they failed to grow in peptone/yeast broth alone or supplemented with arabinose, inositol, lactose, maltose, mannitol, melezitose, melibiose, raffinose, rhamnose, ribose, salicin, sorbitol, starch or xylose. Acid phosphatase was detected by using the API ZYM system; indole was the only positive reaction with the API Rapid ID32A system. By using the

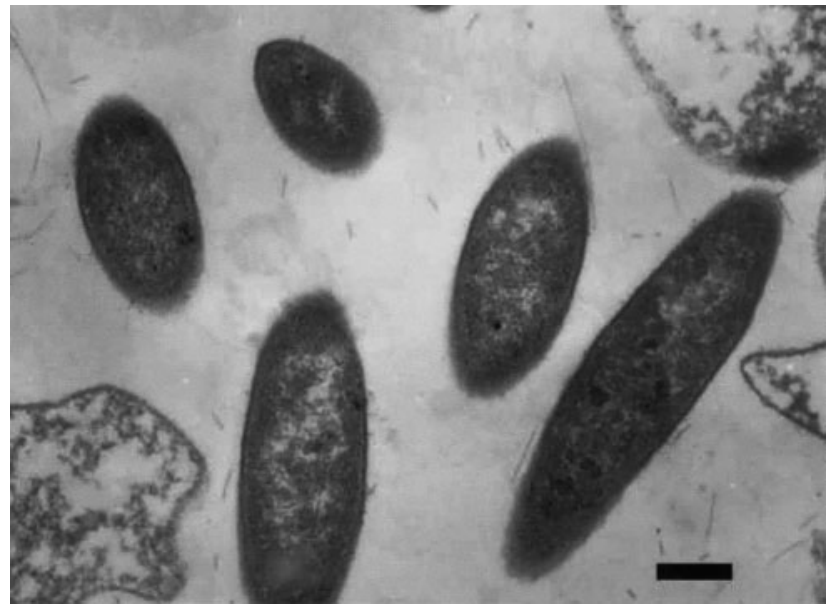

Fig. 1. Transmission electron micrograph of thin-sectioned cells of Anaerotruncus colihominis gen. nov., sp. nov. Bar, $0.5 \mu \mathrm{m}$.

Biolog system, both strains utilized $\mathrm{N}$-acetyl-D-glucosamine, $N$-acetyl- $\beta$-D-mannosamine, arbutin, D-cellobiose, dextrin, D-fructose, D-galactose, D-galacturonic acid, $\alpha$-D-glucose, maltose, maltotriose, D-mannose, methyl 3-D-glucose, methyl $\beta$-D-glucose, methyl $\beta$-D-galactoside, methyl $\beta$-Dglucoside, palatinose, $\mathrm{D}$-trehalose and turanose. The strains also utilized $\alpha$-ketobutyric acid, $\alpha$-ketovaleric acid, L-malic acid, pyruvic acid and pyruvic acid methyl ester. Serine, L-valine, 2'-deoxyadenosine, inosine, thymidine and uridine were also utilized for growth. Utilization of maltose and trehalose for growth varied with the test method: they were utilized for growth in the Biolog system, but not in PRAS broth tests. The isolates were sensitive to vancomycin $(5 \mu \mathrm{g})$ and kanamycin $(1000 \mu \mathrm{g})$, but resistant to colistin $(10 \mu \mathrm{g})$ identification discs.

To determine phylogenetic affinities of the unidentified isolates, their 16S rRNA genes were amplified by PCR and sequenced. The two isolates (WAL $14565^{\mathrm{T}}$ and WAL 15976) were found to be genetically closely related to each other, displaying $100 \% 16 \mathrm{~S}$ rRNA gene sequence similarity. Sequence database searches showed that the unknown bacterium, as exemplified by strain WAL $14565^{\mathrm{T}}$, was a member of the Clostridium subphylum of the Gram-positive bacteria (data not shown). Based on sequence similarity, the closest relatives of the unidentified bacterium were Anaerofilum spp. (87-88\%), Clostridium cellulosi (87\%), Clostridium methylpentosum (88\%), C. leptum (87\%), Clostridium sporosphaeroides (88\%), Eubacterium siraeum (87\%) and Ruminococcus spp. (88-90\%). A tree showing the phylogenetic relationships of the unknown bacterium, constructed by using the neighbour-joining method, is depicted in Fig. 2 and shows that the unidentified rodshaped bacterium is a member of the C. leptum suprageneric rRNA cluster.

The unidentified Gram-positive, asporogenous, rod-shaped 


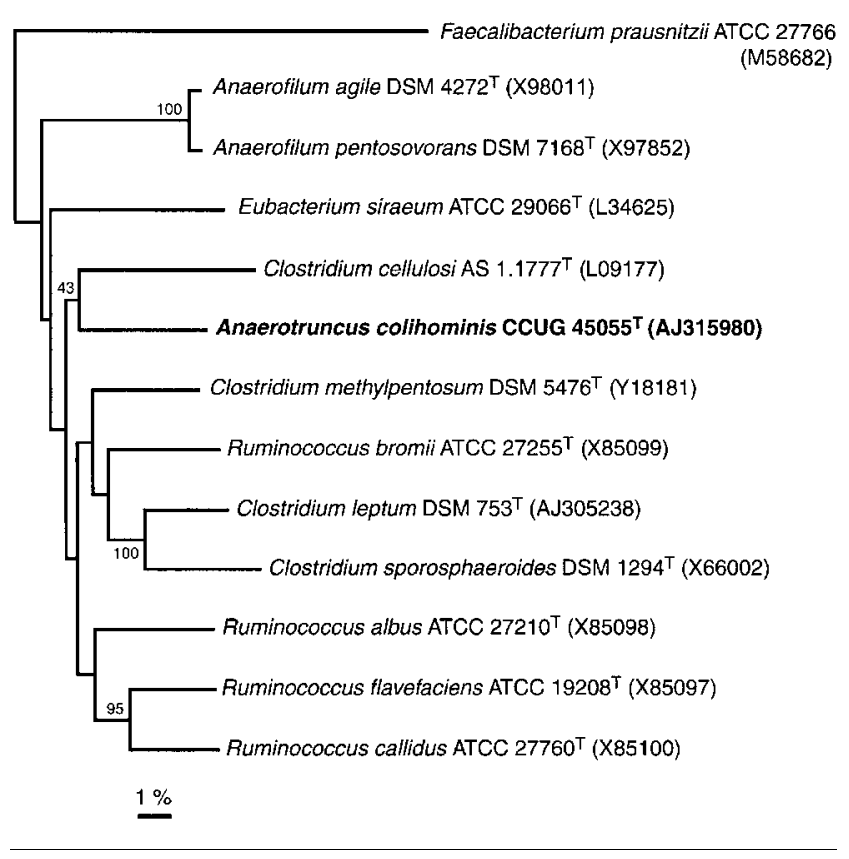

Fig. 2. Unrooted tree showing the phylogenetic relationships of Anaerotruncus colihominis gen. nov., sp. nov. and its close relatives. The tree, constructed by using the neighbour-joining method, is based on a comparison of approximately $1330 \mathrm{nt}$. Bootstrap values, expressed as percentages of 1000 replications, are given at branching points. Bar, $1 \%$ sequence divergence.

organisms clearly represent a hitherto unknown bacterium from human faeces. Phylogenetically, the bacterium forms a distinct lineage of descent within the C. leptum rRNA group (rRNA cluster IV; Collins et al., 1994). This grouping embraces a phenotypically and phylogenetically diverse range of organisms and represents one of three major bacterial phylogenetic lineages within the human gut (Suau et al., 1999). The novel bacterium reported here displays $10 \%$ or greater sequence divergence from described members of the C. leptum group. Although the unidentified bacterium formed a loose association with C. cellulosi on treeing analysis, bootstrap resampling demonstrated that this affinity was not statistically significant. Furthermore, the novel faecal bacterium differs phenotypically from C. cellulosi and all other described taxa within the C. leptum rRNA cluster. In particular, it differs from C. cellulosi and other misclassified clostridial species within this suprageneric cluster by not forming spores. In addition, the unknown bacterium differs from C. cellulosi in end products of glucose metabolism and indole reaction. Furthermore, C. cellulosi is thermophilic and possesses a significantly lower DNA G + C content (35 mol\%) than the unidentified bacterium (54 mol\%) (Yanling et al., 1991). The unknown bacterium can also be distinguished readily from other taxa within the C. leptum rRNA group. For example, it can be distinguished from Anaerofilum spp. (Zellner et al., 1996) by its cellular morphology, carbohydrate fermentation profile and end products of metabolism, and from the misclassified species E. siraeum in acid end products, indole reaction and carbohydrate fermentation profile (Moore et al., 1976). The new organism differs from ruminococcal species by its rod-shaped cells, end products of metabolism and DNA $\mathrm{G}+\mathrm{C}$ content (those of Ruminococcus albus, Ruminococcus bromii, Ruminococcus callidus and Ruminococcus flavefaciens range from 39 to $46 \mathrm{~mol} \%$ ) (Bryant, 1986). The unidentified bacterium also differs markedly from the misclassified species Fusobacterium prausnitzii (Cato et al., 1974) in several key features, such as Gram-stain, indole test and end products of metabolism. Given these phenotypic differences, in concert with the relatively long and distinct phylogenetic sublineage formed by the faecal bacterium within the C. leptum group, we consider that it merits assignment to a novel genus. We therefore formally propose that the two isolates should be classified as Anaerotruncus colihominis gen. nov., sp. nov. Characteristics that are useful for distinguishing Anaerotruncus from closely related taxa within the C. leptum suprageneric group are shown in Table 1.

\section{Description of Anaerotruncus gen. nov.}

Anaerotruncus (An.ae.ro.trun'cus. Gr. pref. an without; Gr. masc. n. aer air; L. masc. n. truncus stick; N.L. masc. n. Anaerotruncus a stick that lives without air).

Cells are Gram-positive, non-spore-forming, thin rods. Strictly anaerobic and catalase-negative. Glucose is fermented. End products of metabolism from peptone/yeast extract broth are acetic and butyric acids. Gelatin is not hydrolysed. Urease-negative. Nitrate is not reduced to nitrite. Indole-positive. DNA G $+\mathrm{C}$ content is $54 \mathrm{~mol} \%$. The type species is Anaerotruncus colihominis.

\section{Description of Anaerotruncus colihominis sp. nov.}

Anaerotruncus colihominis (co.li.ho'mi.nis. L. n. colum colon; L. gen. n. hominis of man; N.L. gen. n. colihominis of the gut of man).

Cells are Gram-positive, non-spore-forming, thin rods, approximately $0 \cdot 5 \times 2-5 \mu \mathrm{m}$. After $48 \mathrm{~h}$ anaerobic incubation at $37^{\circ} \mathrm{C}$ under an $\mathrm{N}_{2} / \mathrm{CO}_{2}(80: 20, \mathrm{v} / \mathrm{v})$ gas phase, colonies are $2-3 \mathrm{~mm}$ in diameter, grey, entire-edged, irregularly shaped, low pyramidal in profile and translucent. $\mathrm{pH}$ range for growth is 5.5-11 and growth temperature range is $36-40^{\circ} \mathrm{C}$. Catalase-negative; nitrate is not reduced to nitrite, but indole is produced. End products of metabolism from peptone/yeast broth are acetic and butyric acids. Aesculin, gelatin and urea are not hydrolysed. Able to grow in peptone/yeast broth supplemented with $1 \%$ glucose, fructose, mannose or cellobiose, but there is no growth in peptone/yeast broth alone or supplemented with arabinose, inositol, lactose, maltose, mannitol, melezitose, melibiose, raffinose, rhamnose, ribose, salicin, sorbitol, starch or xylose. By using the Biolog system, $N$-acetyl-D-glucosamine, $N$-acetyl- $\beta$-D-mannosamine, 
Table 1. Characteristics that are useful for distinguishing Anaerotruncus gen. nov. from closely related taxa within the C. leptum suprageneric group

Taxa: 1, Anaerotruncus gen. nov.; 2, Anaerofilum; 3, C. cellulosi; 4, C. leptum; 5, C. sporosphaeroides; 6, E. siraeum; 7, Faecalibacterium; 8, Ruminococcus. Data from Bryant (1986), Cato et al. (1986), Moore \& Holdeman Moore (1986), Zellner et al. (1996) and Duncan et al. (2002).

\begin{tabular}{|c|c|c|c|c|c|c|c|c|}
\hline Characteristic & 1 & 2 & 3 & 4 & 5 & 6 & 7 & $8^{*}$ \\
\hline Gram-stain & + & $+\dagger$ & - & + & + & + & - & $\mathrm{v}$ \\
\hline Cell shape & Rods & Rods & Rods & Rods & Rods & Rods & Rods & Cocci \\
\hline Spore formation & - & - & + & + & + & - & - & - \\
\hline Motility & - & $\mathrm{V}$ & + & - & - & $\mathrm{V}$ & - & - \\
\hline \multicolumn{9}{|l|}{ Hydrolyis of: } \\
\hline Aesculin & - & $\mathrm{v}$ & + & $\mathrm{v}$ & - & $\mathrm{v}$ & + & $\mathrm{v}$ \\
\hline Cellulose & - & - & + & - & - & - & - & $\mathrm{v}$ \\
\hline Nitrate reduction & - & ND & - & - & - & - & - & - \\
\hline Indole production & + & ND & - & - & - & - & - & - \\
\hline End products of glucose metabolism $\ddagger$ & $\mathrm{A}, \mathrm{B}$ & A, E, F, L, 2,3-butanediol & A, E\$ & $\mathrm{A},(\mathrm{e})$ & $\mathrm{A}, \mathrm{B}, \mathrm{p}$ & A, E & $\mathrm{B}, \mathrm{L}, \mathrm{f}, \mathrm{s},(\mathrm{p})$ & $\mathrm{A}, \mathrm{E}, \mathrm{L}, \mathrm{S}, \mathrm{f}$ \\
\hline DNA G $+C$ content $(\mathrm{mol} \%)$ & 54 & $54-55$ & 35 & $51-52$ & 27 & 45 & $47-57$ & $39-46$ \\
\hline
\end{tabular}

${ }^{\star} R$. albus, R. bromii, R. callidus and R. flavefaciens.

$\dagger$ Old cultures stain Gram-negative.

$\ddagger$ A, Acetic acid; B, butyric acid; E, ethanol; F, formic acid; L, lactic acid; P, propionic acid; S, succinic acid. Minor products are indicated by lower-case letters; products in parentheses may or may not be formed.

§From cellulose for C. cellulosi.

arbutin, D-cellobiose, dextrin, D-fructose, D-galactose, D-galacturonic acid, $\alpha$-D-glucose, maltose, maltotriose, D-mannose, methyl 3-D-glucose, methyl $\beta$-D-glucose, methyl $\beta$-D-galactoside, methyl $\beta$-D-glucoside, palatinose, $D$-trehalose and turanose are utilized. $\alpha$-Ketobutyric acid, $\alpha$-ketovaleric acid, L-malic acid, pyruvic acid and pyruvic acid methyl ester are also utilized. Serine, L-valine, $2^{\prime}$ deoxyadenosine, inosine, thymidine and uridine are also utilized for growth. By using the API ZYM and Rapid ID 32A systems, acid phosphatase and indole activities are detected, but $N$-acetyl- $\beta$-glucosaminidase, alanine arylamidase, alkaline phosphatase, arginine arylamidase, arginine dehydrolase, $\alpha$-arabinosidase, ester lipase C $8, \alpha$-galactosidase, $\beta$-galactosidase, $\alpha$-glucosidase, $\beta$-glucosidase, $\beta$-glucuronidase, glutamyl glutamic acid arylamidase, $\alpha$-mannosidase, $\alpha$-fucosidase, chymotrypsin, alanine arylamidase, leucyl glycine arylamidase, phosphoamidase, trypsin, cystine arylamidase, esterase $\mathrm{C} 4, \quad \beta$-galactosidase-6-phosphate, glutamic acid decarboxylase, glycine arylamidase, histidine arylamidase, lipase $\mathrm{C} 14$, leucine arylamidase, phenylalanine arylamidase, proline arylamidase, pyroglutamic acid arylamidase, serine arylamidase, tyrosine arylamidase and valine arylamidase activities are not detected. Sensitive to vancomycin $(5 \mu \mathrm{g})$ and kanamycin $(1000 \mu \mathrm{g})$, but resistant to colistin sulphate $(10 \mu \mathrm{g})$ identification discs. DNA G $+\mathrm{C}$ content is $54 \mathrm{~mol} \%$.

The type strain is WAL $14565^{\mathrm{T}}=\mathrm{CCUG} 45055^{\mathrm{T}}=\mathrm{CIP}$ $107754^{\mathrm{T}}$. Isolated from human faecal material. Habitat is not known, but is probably the human gut.

\section{Acknowledgements}

This work has been carried out in part with financial support from Veterans Administration Merit Review funds, the Commission of the European Communities and the specific RTD programmes 'Quality of Life and Management of Living Resources' (QLK1-2000-108) and 'Microbe Diagnostics'.

\section{References}

Barcenilla, A., Pryde, S. E., Martin, J. C., Duncan, S. H., Stewart, C. S., Henderson, C. \& Flint, H. J. (2000). Phylogenetic relationships of butyrate-producing bacteria from the human gut. Appl Environ Microbiol 66, 1654-1661.

Bryant, M. P. (1986). Genus Ruminococcus. In Bergey's Manual of Systematic Bacteriology, vol. 2, pp. 1093-1097. Edited by P. H. A. Sneath, N. S. Mair, M. E. Sharpe \& J. G. Holt. Baltimore: Williams \& Wilkins.

Cato, E. P., Salmon, C. W. \& Moore, W. E. C. (1974). Fusobacterium prausnitzii (Hauduroy et al.) Moore and Holdeman: emended description and designation of neotype strain. Int J Syst Bacteriol 24, 225-229.

Cato, E. P., George, W. L. \& Finegold, S. M. (1986). Genus Clostridium Prazmowski 1880, 23 ${ }^{\mathrm{AL}}$. In Bergey's Manual of Systematic Bacteriology, vol. 2, pp. 1141-1200. Edited by P. H. A. Sneath, N. S. Mair, M. E. Sharpe \& J. G. Holt. Baltimore: Williams \& Wilkins.

Collins, M. D., Lawson, P. A., Willems, A., Cordoba, J. J., FernandezGarayzabal, J., Garcia, P., Cai, J., Hippe, H. \& Farrow, J. A. E. (1994). The phylogeny of the genus Clostridium: proposal of five new genera and eleven new species combinations. Int J Syst Bacteriol 44, 812-826.

Ducluzeau, R. (1988). Role of experimental microbial ecology in gastroenterology. In Microbial Ecology and Intestinal Infections, pp. 7-26. Edited by E. Bergogne-Berezin. New York: Academic Press. 
Duncan, S. H., Hold, G. L., Harmsen, H. J. M., Stewart, C. S. \& Flint, H. J. (2002). Growth requirements and fermentation products of Fusobacterium prausnitzii, and a proposal to reclassify it as Faecalibacterium prausnitzii gen. nov., comb. nov. Int J Syst Evol Microbiol 52, 2141-2146.

Gibson, G. R. \& Roberfroid, M. B. (1995). Dietary modulation of the human colonic microbiota: introducing the concept of prebiotics. J Nutr 125, 1401-1412.

Holdeman, L. V., Cato, E. P. \& Moore, W. E. C. (editors) (1977). Anaerobe Laboratory Manual, 4th edn. Blacksburg, VA: Virginia Polytechnic Institute and State University.

Jousimies-Somer, H. R., Summanen, P., Citron, D. M., Baron, E. J., Wexler, H. M. \& Finegold, S. M. (2002). Wadsworth Anaerobic Bacteriology Manual, 6th edn. Belmont, CA: Star Publishing.

Lipman, D. J. \& Pearson, W. R. (1985). Rapid and sensitive protein similarity searches. Science 227, 1435-1441.

Mesbah, M., Premachandran, U. \& Whitman, W. B. (1989). Precise measurement of the $\mathrm{G}+\mathrm{C}$ content of deoxyribonucleic acid by high-performance liquid chromatography. Int J Syst Bacteriol 39, 159-167.

Moore, W. E. C. \& Holdeman Moore, L. V. (1986). Genus Eubacterium Prévot 1938. In Bergey's Manual of Systematic Bacteriology, vol. 2, pp. 1353-1373. Edited by P. H. A. Sneath, N. S. Mair, M. E. Sharpe \& J. G. Holt. Baltimore: Williams \& Wilkins.

Moore, W. E. C., Johnson, J. L. \& Holdeman, L. V. (1976). Emendation of Bacteroidaceae and Butyrivibrio and descriptions of Desulfomonas gen. nov. and ten new species in the genera Desulfomonas, Butyrivibrio, Eubacterium, Clostridium, and Ruminococcus. Int J Syst Bacteriol 26, 238-252.
Nicholas, K. B., Nicholas, H. B., Jr \& Deerfield, D. W., II (1997). GeneDoc: analysis and visualization of genetic variation. EMBNEW News 4, 14

Page, R. D. M. (1996). TREEVIEW: an application to display phylogenetic trees on personal computers. Comput Appl Biosci 12, 357-358.

Rasmussen, S. W. (1995). DNATools, a software package for DNA sequence analysis. Carlsberg Laboratory, Copenhagen.

Steer, T., Collins, M. D., Gibson, G. R., Hippe, H. \& Lawson, P. A. (2001). Clostridium hathewayi sp. nov., from human faeces. Syst Appl Microbiol 24, 353-357.

Suau, A., Bonnet, R., Sutren, M., Godon, J.-J., Gibson, G. R., Collins, M. D. \& Doré, J. (1999). Direct analysis of genes encoding 16S rRNA from complex communities reveals many novel molecular species within the human gut. Appl Environ Microbiol 65, 4799-4807.

Taras, D., Simmering, R., Collins, M. D., Lawson, P. A. \& Blaut, M. (2002). Reclassification of Eubacterium formicigenerans Holdeman and Moore 1974 as Dorea formicigenerans gen. nov., comb. nov., and description of Dorea longicatena sp. nov., isolated from human faeces. Int J Syst Evol Microbiol 52, 423-428.

Wilson, K. H. \& Blitchington, R. B. (1996). Human colonic biota studied by ribosomal DNA sequence analysis. Appl Environ Microbiol 62, 2273-2278.

Yanling, H., Youfang, D. \& Yanquan, L. (1991). Two cellulolytic Clostridium species: Clostridium cellulosi sp. nov. and Clostridium cellulofermentans sp. nov. Int J Syst Bacteriol 41, 306-309.

Zellner, G., Stackebrandt, E., Nagel, D., Messner, P., Weiss, N. \& Winter, J. (1996). Anaerofilum pentosovorans gen. nov., sp. nov., and Anaerofilum agile sp. nov., two new, strictly anaerobic, mesophilic, acidogenic bacteria from anaerobic bioreactors. Int J Syst Bacteriol 46, 871-875. 